\title{
CONTEXTUALIZED SCIENCE LEARNING AND STUDENT'S TRANSITION FROM SECONDARY SCHOOL TO UNIVERSITY: THE CASE OF A PUBLIC DAY SECONDARY SCHOOL IN KENYA
}

\author{
Selline Ooko ${ }^{1 *}$, Festus K. Beru ${ }^{2}$, Samson Madera Nashon ${ }^{3}$ and David Anderson ${ }^{3}$ \\ ${ }^{1}$ Masinde Muliro University, Kenya \\ ${ }^{2}$ KibabiUniversity, Kenya \\ ${ }^{3}$ University of British Columbia, Canada
}

\begin{abstract}
Day schools do not offer boarding facilities, so students report to school in the morning, have their lessons the whole day, and go back home in the evening. In Kenya, Day school students hardly qualify for University admission, partly because of lack of science learning facilities. This research investigated whether contextualized Science learning at a local jua kali workshop could improve students interest and understanding in STEM related concepts and hence contribute to their transition to University. The investigation employed a case study approach where Form three (Grade 11) students from a Day secondary school experienced a 9-week contextualized science learning that involved a full day interaction with Jua Kali1 artisans. The interaction involved students moving in groups at the workshop, observing the processes and discussing relevant scientific concepts with the artisans. Later in school, the groups were tasked with discussing and sharing their best learnt science concepts with the entire class through presentations. The following year, the same students sat for the Kenya Certificate of Secondary Education (KCSE) examination, a National examination done countrywide at the end of secondary school cycle, and the one that determines student's transition to University. In Kenyan Education System, a student with grade C+ and above qualifies for University admission, according to Joint Admission Board (JAB), the body that determines University entrance grades. Based on minimum grade of $\mathrm{C}+$, the school performance improved significantly from $47.48 \%$ to $68.4 \%\left(\mathrm{X}^{2}=7.110^{\prime} \mathrm{P}=0\right.$. 008. From this research, Jua kali workshops could act as a sustainable science learning laboratory for disadvantaged schools with the artisans teaching in collaboration with regular teachers. Thus Contextualized learning using student's local environment could help improve Day school students transition to University.
\end{abstract}

Keywords: Jua Kali, contextualize, curricula

${ }^{1}$ Jua Kali is a small-scale manufacturing and technology-based service sector where artisans manufacture equipment and other household items such as charcoal stoves, kerosene lamps and chicken brooders, which are ubiquitous in Kenyan culture (UNESCO, 1997).

\section{Introduction}

\section{Background to the Study}

In Kenya, most students with poor background, whether in urban or rural setting, attend District (County) Public Day Secondary schools. These schools admit both boys and girls and are also referred to as Mixed schools. In Mixed schools, boys and girls receive the same education, in common rooms by the same teachers, Makewa, Role \& Ngila. Day schools do not offer boarding facilities so students go back to their home after classes and report back the following day for lessons. Day schools in the Urban setting serve children from poor family background. The conditions in urban Day schools resemble their counterparts in the rural setting. In Kenya, this category of schools is predominantly under resourced, and those who attend such schools do so due to lack of funds to pay in the costly single sex boarding schools (Ndunda-Kiluva, 2001). 
Higher Education is the ultimate aim of every parent who has a child in secondary school today whether in Day or Boarding Secondary school. However, there are intolerable inequalities in access to higher education due to geographical, gender, relevance, occupational, and socio-economic reasons amongst others. Equity and access to higher education can never be achieved in the foreseeable future if of necessity equal distribution of learning resources in secondary schools is not adopted. All the learning resources are too expensive to establish and are missing in most Kenyan Day secondary schools. Such schools are not able to provide quality education nor pass students to higher learning institutions. Proportionately fewer children from less privileged backgrounds tend to get promoted into the higher education system. This has the effect of increasing inequality in the distribution of places at the higher education level and disproportionately benefiting children from the more privileged background who can pay to be in boarding schools or well-equipped private schools commonly established in urban centers. Quality education has socio-economic benefits and therefore addressing equity and equality of Education is of great concern. Contextualized learning from student's local environment like Jua kali workshops could offer a cheap, easily available resource for learning Science related concepts. Jua kali workshop and activities are spread all over Kenya. The activities are found in the major cities, local markets and even in villages and their products are the most common tools used in the rural setting in Kenya. Jua Kali artisans are villagers who can communicate to students in very simple language. According to a contextual learning theory (Hull, 1993; Karweit, 1993), learning occurs only when students process new information or knowledge in ways that make it meaningful in their frame of reference e.g. local context. According to Hull, this approach assumes that the mind naturally seeks meaning in a context by searching for relationships that make sense. Thus, students learn better if they can relate the concepts to what they encounter in their day to day life, like jua kali products which they use in the villages. The local environment is rich in materials and activities where students can learn difficult Science concepts without any reference to traditional well equipped science laboratories, well equipped school workshops or even well-equipped libraries that are not available to them. Through contextualized learning, students in Day Schools can improve their grades to $\mathrm{C}+$ and above, the minimum grade for entering into public Universities in Kenya.

\section{Contextualized learning}

The study employed a contextual learning theory (Hull, 1993), which portrays learning as occurring only when students process new information or knowledge in ways that make it meaningful in their frame of reference. According to Hull, this approach assumes that the mind naturally seeks meaning in a context by searching for relationships that make sense. Thus, students learn better if they can relate the concepts to what they encounter in their day to day life. Students from Kenyan Day schools come from rural setting where the main tools used in domestic work comes from jua kali workshop and these workshops are very familiar to them because they are spread all over the country from major towns up to village markets. Examples of jua kali products are pangas, jembes/digging tools, local cooking stoves/jikos, metal boxes, open shoes made from used car tyres, paraffin lamps etc. (Barlett,2004). At jua kali workshop, students would simply observe artisans 'measure a metal sheet, cut it into required sizes, fold and then comes up with a metal box of a specific volume and shape. According to contextualized learning theory, this would be a better approach to teaching and learning, "measurements and volumes", a common topic taught in mathematics at forms two and three levels in Kenyan Secondary Schools, (Klassen,2006; Nashon and Anderson,2013a). Accordingly, contextual learning is organized in ways that allow students opportunities to engage in real world problem solving activities (Karweit, 1993). Learning in meaningful contexts has been determined to be effective (Carraher, Carraher \& Schleimer, 1985). As Resnick (1987) has noted, decontextualizing Science learning has no meaning for the students since it is seen to lack relevance outside of the school. 


\section{General Objective}

To Determine if Contextualized Science learning at a Local Jua Kali workshop can improve Day School Student's transition to University.

\section{Specific objectives}

To determine if contextualized teaching and learning at jua kali workshop can improve day school students' understanding and interest in Science

To determine if contextualized teaching and learning at jua kali workshop can improve the number of Day Schools student getting $\mathrm{C}+$ and above in KCSE

\section{Literature Review}

\section{Education in Kenya}

Education in Kenya is widely seen as one of the most promising paths for individuals to realize better, more productive lives (Eshiwani,1992). The citizens and the Government of Kenya have invested heavily in improving both the access and quality of education, in an effort to realize the promise of education as well as to achieve the education related Millennium Development Goal and Vision 2030 (Government of Kenya,2007) In Kenya, Education consumes about 40\%of Government current budget (TIQUET, 1998) and this excludes parents and community contribution in terms of fees and infrastructure development (Koech, 2000). This makes Education not only the most costly service in the nation but also unaffordable to most Kenyans. Under these circumstances, the whole question of benefit from such an investment has to be reviewed (Sifuna and Otiende,1994). Quality education has socio-economic benefits. For instance, Malenya (2008) posits that 'those with no education earn less than those with formal education and the earnings increase with the level of education. In many countries, attempts have been made to get individual recipients of these benefits (students, parents, and the communities) to pay a bigger share of the cost, a situation already prevalent in Kenya (Mackay, 1981; MoE; 2005). High percentage of Kenyans cannot afford to pay for quality education.

\section{Secondary Schools Education in Kenya}

Secondary schools in Kenya cater for students aged 14 -17years (Njogore and Ole Kerei, 2011; World Bank,2008)), and may be broadly classified as either private schools or public. In another perspective, a major classification may be done in regards to whether the school is boarding or day. Public schools are differentiated into three levels, namely National schools (always boarding), Provincial schools (mostly boarding) and District schools (mostly Day) (Oketch and Somerset, 2010). National schools are considered elite and are the most prestigious government public schools in the country (Glennerster et al., 2011). Compared to other categories, they have better facilities, offer a wide range of subjects (16 subjects compared to 11 in other public schools) and provides high quality peer group. In 2007,80 per cent of teachers in national schools had a degree compared to 68 per cent in other public schools plus the teachers here are twice as likely to hold advanced degree compared to teachers in other schools (Glennerster, et al.,2011). National schools also admit top performers from across the country on a very competitive basis (Oketch and Somerset, 2010). Provincial schools on the other hand are next to national schools and admit the top remaining candidates but from within the same province as the school. They outnumber the national schools by a wide margin and are much easier to access relative (Oketch and Somerset, 2010). And finally, the district secondary schools, also called county schools, at the bottom level (Glennerster, et al., 2011). They serve the local catchments i.e. draw students from schools within the district/county with low grades who could not gain admission into either national or provincial schools (Oketch and Somerset, 2010; Glennerster et al., 2011). There are striking differences across the three 
levels of schools in terms of resources, level of student preparations and examination performance. The differences in facilities, teachers and other inputs perhaps reinforce the differences that exist across them. For example, in $2008 \mathrm{KCSE}$, national schools had 90 per cent while District schools had only 11\% (Glennerster et $a l ., 2011)$. It is also noteworthy that most district schools cannot provide boarding facilities and therefore offer day schooling to pupils living within a reasonable walking distance.

\section{Role of Secondary School Education and Science subjects in Kenyan education system}

In the 8-4-4 (8 years of primary, 4 years of secondary and 4 years of bachelors) system of education currently offered in Kenya, secondary school education acts as a preparatory phase for all tertiary courses and programs, be it at polytechnic, university or other middle level colleges (Tsuma,1998). The Kenya Certificate of Secondary Education (KCSE) obtained at the end of four years in secondary school is perhaps the most important document a student in Kenya needs to access a good profession. Mathematics and science based subjects (chemistry, physics, and biology) form the core subjects in secondary education (KIE,2002). In Kenya, it is usually easy for above average student to obtain good grades, say "A" in most subject they sit for at KCSE, (history, geography, religion, Business Studies, computer etc.) but fail with a very low grade of bellow B in Mathematics and Science. A low grade or failure in Mathematics and or Science lowers the student's overall points and automatically prevents him/her from getting into strong courses like Law, Engineering, Medicine and Architecture at the University. Parents with children in secondary schools have noticed the problem of high failure rate in science and mathematics and are now sending their children for special tuition during holidays, but at a heavy fee. Parents of Children in less privileged schools cannot afford holiday tuition. In Kenya, good performance in science and mathematics at the national examinations level - Kenya Certificate of Secondary Education (KCSE) is commonly registered by schools with well-equipped science laboratories and qualified teachers. No wonder it is most parents' dream to take their children to National schools with the belief that these schools are better at preparing students for university entrance at the end of secondary school phase. Therefore, the value of using other strategies to teach or learn science at Secondary School level cannot be underestimated.

\section{Performance in Science and Mathematics in Kenyan Secondary Schools}

The Government of Kenya recognizes the importance of science and mathematics in the realization of its vision 2030; to become a globally competitive and prosperous country by 2030 . This is reflected in amount of resources both human and otherwise that are channeled towards enhancing the teaching and learning of science and mathematics at all levels of education system (MoE,2005; Lewin,2007). However, this high input does not seem to be reflected in the performance (Yara and Wnjohi,2011). Analysis of KCSE result every year show poor performance in science and mathematics as compared to other subjects like history (KNEC, 2011). This trend was noted in Kamunge Report, 1998 and recommendations were made that more facilities be provided for science and mathematics teaching. Following this, a number of intervention strategies have been put in place to ensure that the teaching/learning of science and mathematics is as effective as possible. Apart from providing science teachers, the Government has institutionalized Service Education and Training,(INSET) for science and mathematics teachers under the Strengthening of Mathematics and Science in Secondary Education (SMASSE) Programme (Oduor,2009).Schools on the other hand are charged with providing, learning resources /facilities through Board Of Governors (BOGs) and Parents Teachers Associations(PTAs).A number of organizations also offer laboratory equipment to support science education (Kamunge, 1998). In spite of all these initiative, KCSE performance in the sciences and mathematics is still poor (Gerard et al., 2001). This study aimed to explore Jua Kali sector as a cheap, sustainable, easily accessible secondary school science teaching resource to improve performance in the sciences and mathematics and to improve on University intake of Day Secondary Schools in Kenya. 


\section{Challenges and Academic Performance; Day Vs Boarding Secondary Schools}

Virtually, every social and economic indicator shows the extreme inequalities that exist between different societies in Kenya (Republic of Kenya, 2006). Academic Performance has also often been found to vary depending on the category of the secondary schools, either sinle sex Boarding or mixed Day school. Despite these two categories of schools following the same syllabus and sitting the same examinations, disparities in performance have continued to be noted every year. Several reasons have been given to account for these variations in performance with Day-secondary schools at a lower level. Some authors like Kenari et al,.1995, attributes it to teacher's method of teaching, while Jagero (1999) attributes it to lack of facilities and poor discipline in some schools. The high cost of schooling is also a major factor as this accounts for $30 \%$ of those unable to access education at secondary level (Ministry of Education, 2005a). Most parents of students in rural Day-secondary schools are peasants, whose land products do not pay constantly, and regularly. UNESCO (2000) confirms that in established Secondary, schools, student attendance is often three times greater, than in Day Schools mainly due to low economic status of the parents (Lewin,2007). Absence from school, negatively affects the performance, (Oigara,2011). Students in Day-secondary schools, have difficulty in buying necessary material that assists learning.

The Kenya National Development Plan for the period 1997-2001 acknowledges that, Kenya faces serious problems in the education front, primarily related to the decline in the quality of education. United Nations (2001) observed that, children from lower category schools are intellectually and educationally inferior, to National and Provincial school counterparts. In their study, they frequently showed that Students in wellestablished Boarding schools perform better on standardized tests than those in District school. World Bank (2005) observed that, teachers in rural areas are demotivated, as they are forced to teach in remote and inaccessible areas, where parents are too poor to motivate them. This is unlike the established National and provincial secondary schools, where teachers are rewarded for their efforts by parents, through cash remunerations or promotions of individual teachers. Novicki, (2012) also noted that students from public Day schools are disadvantaged in performance because books for use in schools, rarely include materials reflecting their local environment. Examinations have been used as a cognitive measure of internal efficiency, knowledge and skills acquired in school, yet they do not take into account the environment (Nashon,2013). As Yoloye (1986) confirms, education is not considered as a priority in some local community because the type of education provided does not fulfill their needs or aspirations and has no reference to their societal needs (Yara and Wanjohi,2011). The failure by the educationists to make the school curriculum more relevant to the local needs, has led to marginalization of a number of Communities in Kenya (Knamiller,1984) because, the curricula are largely, urban and colonial biased. Content analysis of books, has also been observed to reveal biases, in favor of children of the rich who are exposed to modern technology like videos and computers. This is despite the fact that, the qualifying examinations the KCSE is the same for both. This study sought to use student's local environment as a Science and Mathematics teaching aid (Nashon, et al., 2011) to form three students in a Day school, with an aim of making their learning more interesting, more effective and relevant to their life in the local setting, and to finally improve their KCSE grade to a minimum of $\mathrm{C}+$, the minimum requirement for admission into Kenyan Public University.

\section{Methodology}

\section{The study was implemented as follows:}

Initially the study was introduced to four Science teachers (mathematic, physics, chemistry and biology) of Form 3 classes in a selected Day Secondary school. Upon accepting to be involved in the research, the teachers and the researchers visited a local Jua Kali site, surveyed it and identified varieties of products and production activities that could be linked to school science based curriculum or could be understood in terms of school science and Technology as well as attract students' curiosity and attention to understand the embedded Science 
and Mathematics concepts. In collaboration with Jua Kali artisans, the teachers and researchers divided the site into ten production stations to ensure that the students engaged in Science and Mathematics learning through interaction with variety of products, production activities and the artisans.

Later in a workshop format the teachers and researchers identified topics from the Form 3 science related curriculum that are related to Jua Kali products and production activities. The teachers then developed guiding questions that could enable students engage in discussion with Jua Kali artisans and their peers at the jua kali workshop. After the first ja kali workshop visit, the teachers, equipped with the general framework for implementing the integrated science unit, organized introduction sessions with the Form 3 class that was aimed at sensitizing or cueing the students to/on the potential role local contexts could play in enhancing their understanding of Scientific concepts. The role of researchers and the aim of the study was clearly explained to students.

One day after the teachers cued the class of the potential benefits of Jua Kali as a site to engage in STEM learning, the students, teachers and researchers organized and visited a local Jua Kali workshop where the students used the guiding questions to interact with Jua Kali artisans as they sought important information on the products and production activities for about four hours. The artisans were the sole instructors during this workshop tour.

Back in class, the visit was followed by a one-hour in-class activity that required students to reflect on the science and Technology embedded in at least one Jua Kali product and production activity they had experienced during the visit. They then had to make a 10-minute group presentation on a product and production activity that evoked most STEM knowledge and using classroom gained scientific knowledge they had to suggest possible modifications to improve the product and production activity. The same students sat for their final National Examination, the KCSE one year after exposure to jua kali activities. The impact of contextualized learning at the Jua Kali workshop was analysed and recorded.

\section{Analysis and Findings}

Data analysis is an attempt to summarize the data that have been collected in a dependable, accurate, reliable and correct manner (Mills, 2003; Mugenda and Mugenda,2003). One year later, the students having reached their final year, sat for KCSE. Grades attained that year were collected and analyzed for any significant improvement in number of students with grade $\mathrm{C}+$ and above and so qualify for University Admission. The figure below (Fig 1) shows the analysis of KCSE results of 2 streams with 40 students each from a County/District Day School in Kenya who experienced the contextualized science unit. The overall mean grades were subjected to statistical analysis to determine if there was any significant improvement in University admission based on grade of $\mathrm{C}+$ and above as compared to the previous year grades of candidates who did not go through contextualized science learning experience. The results are shown below (Fig 1): 
Effect of Jua kali learning experience on University intake according to Joint Admission Board (JAB) minimum grade of $C+$

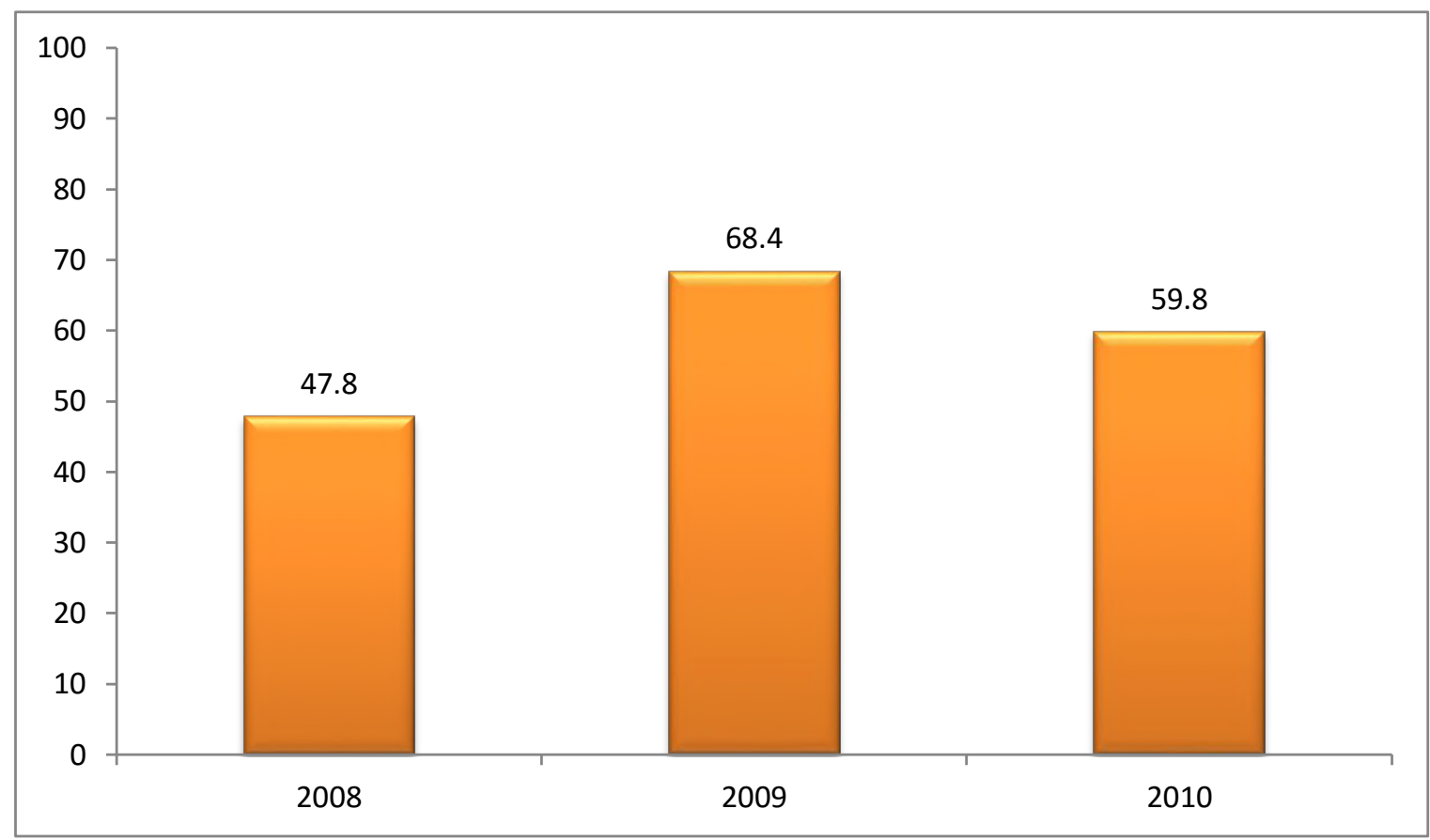

Fig 1; Percentage Admission based on JAB for school A

In school A, there was a significant increase in JAB admission from $47.8 \%$ in 2008 to $68.4 \%$ in 2009 ( $\chi 2=7.110$, $\mathrm{p}=0.008$ ). However, it decreased to 59.8\% in 2010 (the year with no contextualized learning intervention), though not significant $(\chi 2=1.65, \mathrm{p}=0.199)$.

Intake according to JAB minimum grade of C+ in anon Intervention school, (control)

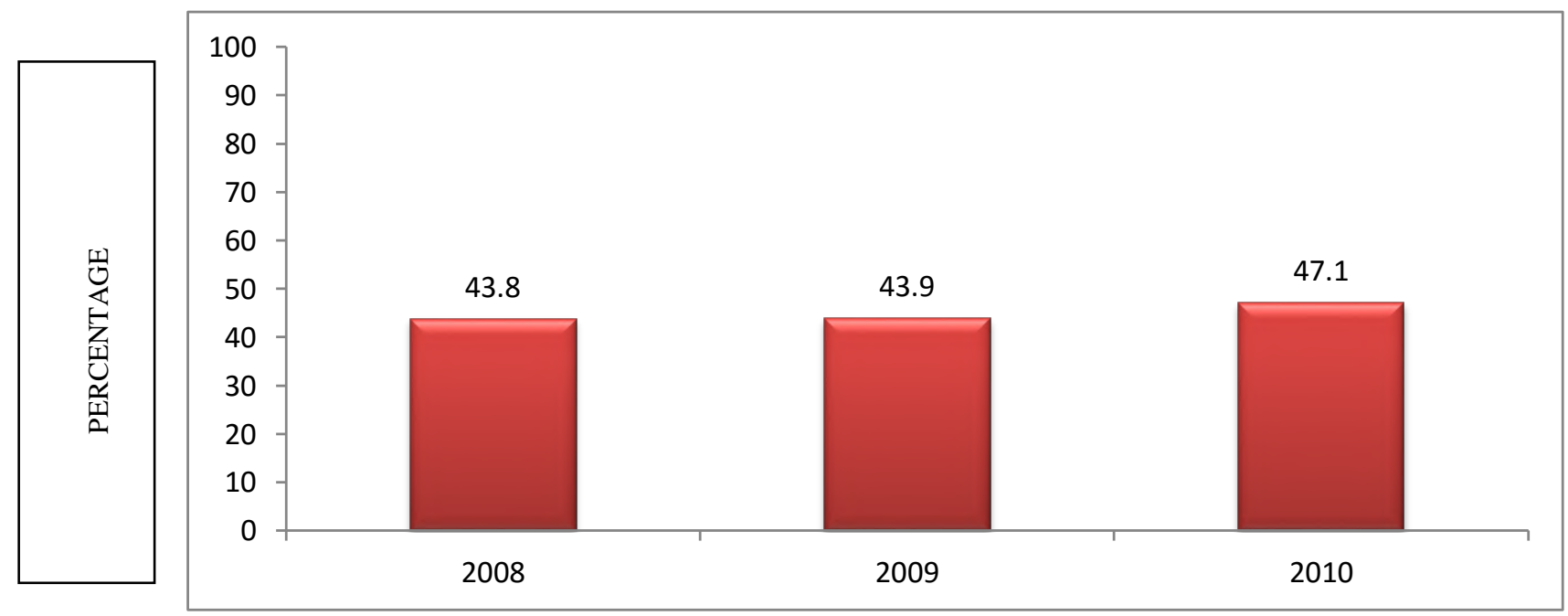

FIG 2; Percentage Admission based on University Joint Admission Board (JAB)for school B

There was a significant improvement on University Admission based on Joint Admission Board (JAB) minimum grade of $\mathrm{C}+$ and above in the Day School (school A) from before to after Jua Kali learning experience (, 47.8\% in 2008 to $68.4 \%$ in 2009 ( $\chi 2=7.110, p=0.008)$. School B, a mixed Day school in the neighborhood, who did not go through the same experience but sat the same KCSE did not record any significant improvement in their University admissions. Since the two schools, A and B are known to share a lot of learning resources, 
like subject teachers, laboratory equipment, end of term grade tests among others, it is possible that the teaching and learning at jua kali helped improve interest and attitude of student of school A, who now perfumed better than their neighbor school(B). Mathematics and Science teachers in Day schools should be made aware of the availability of science learning tools within their surrounding and at no cost. Students do not have to wait forever for the teaching materials to be bought for the science syllabus to be completed within the speculated time frame,

\section{Discussion and Conclusion}

\section{Educational Significance}

Although Kenyan Secondary school enrolment has risen tremendously, the passage to university was below the expected 15 per cent target for 2012 for example (Glennerster et al., 2011).One way to mitigate this is by finding a sustainable method of encouraging quality education to the disadvantaged secondary schools, such that their products can also attain University Education. The findings from this study are important because it has shown that the bridge between classroom teaching and local setting can be shortened. The results have a strong potential of helping STEM teachers realize the importance of the school's local environment as teaching aid. Majority of Secondary schools in Kenya are in the category of Rural, Day mixed type. These schools lack teaching aids especially for science subjects. This could be the reason for not only lack of interest and high school dropouts at Secondary School level but also low entry into higher learning institutions. Jua Kali workshops are found almost in every market place in Kenya. The artisans are locals capable of passing information to students using very simple local codes which every student can understand. After all they would have had the experience of the phenomena and concepts in their own cultural set up. In other words, the students will in this case have a narrower border to cross into the difficult concepts especially mathematics and science than would have been the case in a strictly contrived school laboratory experiments. Therefore, results from this research could offer solution to low transition from secondary schools to university especially to those in rural set up who lack most basic requirement for quality learning and are unlikely to compete for limited space in public university with students from well-established and high cost schools. Products from Jua Kali include cooking stoves, farm tools, brooders, sandals and paraffin lamps. These items are found in villages and students are very familiar with them having used them in one way or another. Improved number of students with minimum requirement for university admission demonstrated that our environment can be a substitute for expensive teaching materials for those rural county schools who cannot afford expensive equipment. Importantly, this research provides teachers with information that is useful in their attempts to bridge the divide that exists between classroom knowledge and local settings that have the strong potential to assist the learners to develop broader thinking capacity and a clearer interpretation of scientific concepts based on their socio cultural setting.

\section{Conclusion}

The Kenya Certificate of Primary Education (KCPE) and Kenya Certificate of Secondary Education (KCSE) are national achievement tests at the primary and secondary levels respectively often relied upon for certification and selection for progression to higher levels of education. Historical data (from 2001) emanating from these tests indicate that private academies and established National schools (where children of the rich attend), perform better than public schools at lower categories (World Bank,2005). The reason is that, schools serving low-income students, especially in rural areas in Kenya receive less resource, face insurmountable challenges in attracting and retaining qualified teachers, are rarely inspected for quality, and receive less support from the school community. The bottom-line is that education in Kenya is still highly capitalistic, sold to the highest bidder. Children from poor families are therefore most disadvantaged by the education system, and are likely to be condemned to lesser professional and employment prospects. The findings from this research have thrown some light to this problem by exposing STEM teachers at secondary level to the rich science teaching 
laboratories offered by not only jua kali workshop but the whole array of our natural environment. If these findings are incorporated into Day School by STEM teachers, this could be the beginning of rural students reaching University and getting into strong course like medicine and Engineering.

\section{References}

Bartlett, A. and M. Jatiket (2004). Growing Up in the Real World Contributes to Enhance the Quality of Education for Rural People. Thai Education Foundation, Bangkok.

Carraher, T., Carraher, D., \& Schleimer, A. (1985). Mathematics in the streets and in schools. British Journal of Developmental Psychology. 3, 21-29.

Chebari, E. (2010) Challenges facing effective implementation of free Secondary Education in public Secondary Schools in Kagundo District, Kenya. MA Thesis .(Unpublished).

Eshiwani, G. S. (1992). The Quality of Secondary Education in Kenya. Nairobi: East African Educational Publishers

Glennerster, R.; Kremer, M.; Mbiti, I; Takovarasha, K.; Lalif, A. (2011) Access and quality in the Kenyan Education system: A review of the progress, challenges and potential solutions. Prepared for the office of the Prime Minister of Kenya.

[http://www.povertyactionlab.org/publication/access-and-quality-kenyan

education-system(Accessed on 02/01/2013)]. 14

Griffins V L (1968).The Problems of Rural Education. UNESCO: I.I.E.P. United Nations

Government of Kenya (2007), Vision 2030, Ministry of Planning, Nairobi, Government printer.

[http://www.build-africa.org/news.php/69/the-threat-to-free-primary-education-in kenya(Accessed on 02/01/2013)].

Hull, G. (1993). Hearing other voices: A critical assessment of popular views literacies and work. Harvard Educational Review. 63(1).

Jagero N O (1999). “An Evaluation of the Factors Affecting the Quality of Education in Day Secondary Schools in Kenya: A case study of Kisumu Sub county”, Unpublished M.Phil. Thesis, Moi University.

Kamunge, J. (1988). Report of the presidential working party on education and manpower development for the next decade and beyond. Nairobi, Kenya: Government Printer.

Karani F, Wainaina G, Anyangu M A, Okumbe J A \& Getau KW (1995). Cost and Financing of Education in Kenya: Study 2: Access, Quality and Equity in Education and World Bank.

Karweit, D. (1993). Contextual learning: A review and synthesis. Baltimore, MD: Center for the Social Organization of Schools, Johns Hopkins University Press.

Kenya Institute of Education (KIE,2002). Secondary Education syllabus: Kenya Literature Bureau, Nairobi Kenya.

Klassen, S. (2006). A theoretical Framework for Contextual Science Teaching. Interchange. Springer Link,37 (1) $31-62$

Koech, D. (2000). The commission of inquiry into the education system of Kenya.Nairobi, Government printer

Knamiller, G. W. (1984). The struggle for relevance in science in developing countries. Studies in Science Education. 11, 60 - 78.Government Printer.

KNEC, (2005). Kenya Certificate of SecondaryEducation; Regulations and Syllabuses,20062007,KNEC,Nairobi.

KNEC,(2004).Kenya Certificate of Education Repport,Nairobi,Kenya.

K.N.E.C, (2007). The year 2006 Kenya Certificate of Education

Lewin, K. (2007) Expanded access to secondary schooling in Sub-Saharan Africa: Key planning and finance issues. CREATE PATHWAYS TO ACCESS RESEARCH Monograph No.8. [http://sro.sussex.ac.uk/1838/1/PTAs.pdf (Accessed on 13/012/2012)]

Mackay, C.B., (1981). Second university in Kenya: Report of presidential working party. Nairobi, Kenya: Government Printer 
Malenya, F. L. (2008). The Free Secondary Education Agenda. Nairobi: Kenya Institute of Education

Mills, E. G. (2003).Action research: a guide for the teacher researcher ( $2^{\text {nd }}$ Edition). Upper Saddle River, New Jersey: Merrill Prentice Hall.

MoE,(2005).Kenya Education Support Programme,2005-2010,M.O.E.,Nairobi

Mugenda, O. M., \& Mugenda, A. G. (2003). Research methods: Qualitative and quantitative approaches. Nairobi: Acts Press.

Nashon, S. M., Ooko, S.\&Beru, F. K. (2011). Understanding, interpreting and profiling Kenyan students' worldviews of science learning. Journal of Technology and Socio-economic Development, 1(1), 346 - 352

Nashon, S. M. (2013). Interpreting Kenyan science teachers' views about effect of student learning experiences on their teaching.Canadian Journal of Science, Mathematics and Technology Education, 13(3), 213 - 231

Nashon, S. M., \& Anderson, D. (2013a). Interpreting student views of learning experiences in a contextualized science discourse in Kenya.Journal of Research in Science Teaching. 50(4), 381-407

Nashon, M. S. \& Anderson, D. (2013b). Teacher change: The effect of student learning on science teachers' teaching in Kenya. International Journal of Engineering Education, 29(4), 1 - 7

Ndunda-Kiluva, M. (2001). Women's agency and education policy: The experience of the women of Kilome, Kenya. NY: State University of New York Press.

Njoroge, J. \& Ole Kerei, K. (2010) Free day secondary schooling in Kenya: An audit from cost perspective. International Journal of Current Research.

[http://www.lournalcra.com/?q=node/1265(Accessed on 02/01/2013)]

Novicki M A (2012). Boosting Basic Education in Africa, Special Initiative, World Bank.

Oduor,H.N.,(2009).The effect of Strengthening of Mathematics and Sciences in Secondary Education (SMASSE)Training on Performance of students in chemistry in Uasin- Gishu Couty,Kenya.(Unpublished M.Phil.Thesis,Moi University Eldoret,Kenya.

Oigara, J. (2011). Effect of school environment on student achievement and self-achievement: A case study in Kenya. International Journal of Humanities and Social Science, 1 (7), 84-88.

Oketch, M. \& Somerset, A. (2010) Free Primary Education and after in Kenya: Enrolment impact, quality, effects, and the transition to secondary school. Create (Consortium for Research on Educational Access, Transition and Equity). Research Monograph No. 37. [http://www.create-rpc.org/pdf_documents/PTA37.pdf (Accessed on 20/01/2013)]

Ominde, S. H. (1964a). Kenya Education Committee Report, Part I. Nairobi, Kenya: Government Printer.

Otiende, J.E., Wamahium, S.P., \& Karagan, A.M. (1992). Education and development in Kenya: A historical perspective. Nairobi : Oxford University Press.

Oyaro, K. (2013) Free secondary schooling policy faces testing times. Inter press service (IPS)News Agency. [http://www.ipsnews.net/2008/03/kenya-freesecondaryschooling-policy-faces-testing-times/(Accessed

on 02/01/2013)]..

Republic of Kenya (2006). Ministry of Education Strategic Plan 2006-2011. Nairobi: Government Printer

Republic of Kenya. (2007): The Kenya Vision 2030. Transforming National Development

Resnick, L. (1987). Education and learning to think. Washington, DC: National Academy Press.

Sifuna, D.N. \& Otiende, J. E. (1994). An introductory history of education (2nd ed.). Nairobi: Nairobi University Press.

TIQUET,(1998).Total Integrated Quality Education and Training

Tsuma, O. G. K. (1998). Science Education in the African context. Nairobi: Jomo Kenyatta Foundation, ISBN 9966-22-145-X.

UNESCO (2004). Education inequality at School and Education Policies. Paris, UNESCO

UNESCO (2000): The Dakar Framework for Action: Education for All: Meeting our Collective Commitments. Paris: UNESCO. Derived from the World Education Forum proceedings, Dakar, Senegal, April. 
UNESCO (1997)" Under the Sun or in the Shade? Jua Kali in African Countries". National Policy Definition in Technical and Vocational Education beyond the Formal Sector. A Sub-regional Seminar for Eastern and Southern African Countries, Nairobi, Kenya, September 15 - 19.

United Nations (2001). Human Development Report Addressing Social and Economic Disparities for Human Development in Kenya, World Bank.

World Bank (2009). Secondary Education: An Overview Retrieved from http://web.worldbank.org/wbsite/external/topics/exteducation/

World Bank (2008). Governance, Management, and Accountability in Secondary Education in Sub-Saharan Africa, Washington DC: World Bank.

World Bank (2005). Expanding Opportunities and Building Competencies for Young People: A New Agenda for Secondary Education, Washington D.C.: World Bank.

Yara, P. and Wanjohi, C. (2011). Performance determinants of Kenya Certificate of Secondary Education (KCSE) in mathematics of secondary schools in Nyamira Division, Kenya.

Yoloye, E. A. (1986). The relevance of educational content to national needs in Africa. International Review of Education. XXXXII, 149-172. 